\title{
Assessing microcirculation dynamics during gait in the lower limb - a preliminary approach
}

\author{
Avaliação da dinâmica microcirculatória no membro inferior durante a marcha - uma \\ abordagem preliminar
}

\author{
Margarida Florindo ${ }^{1,2}$, Henrique Silva ${ }^{2,3}$, L. Monteiro Rodrigues ${ }^{2,3}$ \\ ${ }^{1}$ Department of Physiotherapy, Portuguese Red Cross Superior Health School, ESSCVP Lisboa, Portugal \\ ${ }^{2}$ CBIOS - Universidade Lusófona's Research Center for Biosciences and Health Technologies, Lisboa, Portugal \\ ${ }^{3}$ Pharmacol. Sc Depart — Universidade de Lisboa, Faculty of Pharmacy, Lisboa, Portugal \\ Email: mflorindo@esscvp.eu
}

\begin{abstract}
Gait is a daily life activity that requires a permanent combination between skeletal muscle mechanical stimuli with other hemodynamic systems, such as the regulation of blood flow. This is a preliminary study to identify the potential adaptations occurring in the lower limb microcirculation during loading and suspension phases of gait. Six subjects $(25.8 \pm 5.4)$ were evaluated during a protocol performed in three phases: 1 minute of both feet support, 1 minute of light steps in the same place and 1 minute similar to the initial phase. Skin microcirculation was noninvasively assessed by the Tissue Viability Imaging ${ }^{\circledR}$ System (TiVi) in both feet (expressed in AU's). Pulse rate (PR) was measured with a photoplethysmography system (PPG). Descriptive and comparative statistics were applied, and a confidence level of $95 \%$ adopted. Our preliminary data detected a physiological variation during gait in the suspension phase of stepping, compared with the loading phase. When the foot is cyclically on the floor, the values are similar to the resting phase. Further studies are needed to look deeper into the microvascular behaviour on the lower limb during the gait cycle.
\end{abstract}

Keywords: Microcirculation, lower limb, gait, blood perfusion TiVi

\section{Resumo}

A marcha é uma atividade de vida diária que requer uma combinação permanente dos estímulos mecânicos músculo esqueléticos com outros sistemas hemodinâmicos, como a regulação do fluxo sanguíneo. Este é um estudo preliminar para identificar as possíveis adaptações que ocorrem na microcirculação do membro inferior durante as fases da marcha em carga e em suspensão. Foram avaliados seis sujeitos $(25,8 \pm 5,4$ anos de idade) durante um protocolo realizado em três fases: 1 minuto de apoio de ambos os pés, 1 minuto de passos leves no mesmo local e 1 minuto semelhante à fase inicial. A microcirculação da pele foi avaliada de forma não invasiva pelo sistema Tissue Viability Imaging ${ }^{\circledR}$ System (TiVi) em ambos os pés (expresso em Unidades Arbitrárias). A frequência de pulso (FP) foi medida com o sistema de fotopletismografia (FPG). Foram aplicadas estatísticas descritivas e comparativas e adotado um nível de confiança de $95 \%$. Os dados preliminares detetaram uma variação fisiológica durante a marcha na fase de suspensão do passo, em comparação com a fase de carga. Quando o pé está ciclicamente no chão, os valores são semelhantes à fase de repouso. Mais estudos serão necessários para aprofundar o comportamento microvascular no membro inferior, durante o ciclo da marcha.

Palavras-chave: Microcirculação, membro inferior, marcha, perfusão sanguínea, TiVi 


\section{Introduction}

Gait is a complex current activity of our relational life that creates alternating periods of weight support and suspension on the lower limb. These constantly generate changes in the morphology of the lower limb structures, whose coordination may affect the multisystem autoregulation [1]. The gait cycle can be defined as the time between two contacts of the same heel on the floor and is divided in two phases: a support phase $-60 \%$ of the total gait time, and a no support phase $-40 \%$ of the total gait time [2-3]. The multivariable, dynamic footankle mechanical system is influenced and permanently influencing all the gait tasks and subtasks that includes body translations and horizontal as vertical ground reaction forces [4]. Not much has been published regarding the microcirculatory dynamics following the different phases of gait, although we know that it represents a major determinant of movement [5-6].

During walking, muscular contraction produces an elevation of the intramuscular pressure, compressing the blood vessels and evoking a cyclical reduction of the microcirculation that corresponds to each step performed [4]. Associated with this phenomenon, the compression exerted on the plantar venous plexus during gait is a mechanism that prepares and stimulates all the pumping that occurs consequently in the leg [7]. The vascular variations that occur with orthostatic stress have been studied in order to perceive the gravitational displacement of blood in lower limbs with postural changes [8]. The alterations of the blood volume in the periphery during the movement and especially during the real time of the gait, however, have not yet been studied. The present study is, therefore, a preliminary investigation to identify the potential adaptations occurring in the lower limb microcirculation during loading and suspension phases of gait.

\section{Materials and Methods}

Six healthy young adults $(25.8 \pm 5.4$ y.o. $)$, both genders (four female and two male), normal BMI with no history of cardiovascular or musculoskeletal disorders, participated in this study after giving informed written consent. All procedures complied with the Helsinki Declaration and subsequent amendments [8]. Measurements were taken in a room with controlled conditions,

\section{Introdução}

A marcha é considerada uma atividade funcional da vida diária, de grande complexidade que exige períodos alternados de suporte de peso e suspensão no membro inferior. Estes períodos geram constantemente mudanças na morfologia das estruturas dos membros inferiores, cuja coordenação pode afetar a autorregulação multi-sistémica [1]. O ciclo de marcha pode ser definido como o tempo entre dois contatos do mesmo calcanhar no chão e é dividido em duas fases: uma fase de apoio que equivale a cerca de $60 \%$ do tempo total da marcha e uma fase sem apoio equivalente a $40 \%$ do tempo total de marcha [2-3]. O sistema mecânico multivariável e dinâmico do pé / tornozelo é influenciado e influencia permanentemente todas as tarefas e sub-tarefas da marcha, incluindo as translações do corpo e as forças horizontais de reação vertical do solo [4]. Existem poucas publicações sobre a dinâmica da microcirculação durante as diferentes fases da marcha, embora saibamos que se apresenta como um fator determinante durante o movimento dos membros inferiores [5-6].

Durante a marcha, a contração muscular produz uma elevação da pressão intramuscular, comprimindo os vasos sanguíneos e evocando uma redução cíclica da microcirculação que corresponde a cada passo realizado [4]. Associada a esse fenômeno, a compressão exercida no plexo venoso plantar durante a marcha é um mecanismo que prepara e estimula todo o bombeamento que ocorre consequentemente na perna [7]. As variações vasculares que ocorrem com o stress ortostático têm sido estudadas para se perceber o deslocamento gravitacional do sangue nos membros inferiores perante as alterações posturais [8]. No entanto, as alterações do volume sanguíneo à periferia dos membros inferiores durante o movimento e principalmente durante o tempo real da marcha, ainda não foram estudadas. O presente estudo surge, como uma investigação preliminar para identificar as possíveis adaptações que ocorrem na microcirculação do membro inferior durante as fases de carga e suspensão da marcha.

\section{Material e Métodos}

Seis adultos jovens e saudáveis $(25,8 \pm 5,4$ anos de idade), com IMC (Indice de Massa Corporal) normal, ambos os sexos (quatro mulheres e dois homens), que apresentam um Índice de Massa Corporal normal $(22,13 \pm 3,3)$, sem história de doenças cardiovasculares ou músculo-esqueléticas, participaram deste estudo após assinarem um consentimento informado. Todos os 
including temperature $\left(25 \pm 1{ }^{\circ} \mathrm{C}\right)$ and humidity $(40 \%$ $-60 \%)$.

Subjects performed the protocol after an acclimatization period involving 1 minute with both feet flat on the floor (Phase I), 1 minute of light stepping (1step/sec) in the same place (Phase II) and 1 minute recovery, resuming the initial posture (Phase III).

Perfusion was noninvasively assessed by the Tissue Viability (TiVi, Wheels Bridge, Sweden) system, a polarized spectroscopy device consisting in a digital camera coupled to cross-polarizing filters in front of the detector array, which linearly polarize visible light from the light source. Part ( $\sim 7 \%)$ of the incident light is reflected with the original polarization state by the skin surface, and will be blocked or attenuated by the filters. The remaining light will be diffusely backscattered in a depolarized state due to scattering and birefringence events in the upper dermal layers [9], where the microcirculatory vessels are located, and will reach the detector array. The photo is transmitted from the camera to the computer, where colour plane separation is performed. Applying an algorithm based on data from the red and green colour planes yields a pseudo-colour image, of whose TiVi value in each pixel is proportional to the concentration of moving red blood cells $(\mathrm{CMBC})$ within the actual scattering volume in tissue. This algorithm is based on the knowledge that green wavelengths are absorbed by haemoglobin in circulating red blood cells, while red wavelengths only suffer a minor absorption [10]. The TiVi index expressed in arbitrary units (AU),was assessed at a $6 \mathrm{~Hz}$ sampling rate, and the region of interest (ROI) selected on the dorsum of both feet, anterior to the ankle joint (Figure 1). The camera was placed at $100 \mathrm{~cm}$, which allowed to keep the limb at a distance greater than $60 \mathrm{~cm}$, eliminating the temperature and light intensity influence of the camera [11].

During the gait phase (Phase II), the TiVi index was assessed in two sub-phases - when each foot was flat on the floor, supporting the body weight (loading phase - LP), and when each foot was suspended (suspension phase - SP). For each sub-phase, the TiVi index was calculated as the mean value of all gait cycles.

The pulse rate (PR) was evaluated with a photoplethysmography (PPG) sensor (Blood Volume Pulse sensor, PLUX Biosignals, Portugal), placed on the second finger of the right hand, and connected to a BITalino Plugged microprocessor board (PLUX Biosignals, Portugal).

Results were expressed as the mean values for each foot. The Wilcoxon signed-rank test was used for phase comparisons within each foot, and the Mann-Whitney procedimentos cumpriram a Declaração de Helsínquia e as emendas subsequentes [8]. As medidas foram realizadas numa sala com condições controladas, incluindo temperatura $\left(25 \pm 1^{\circ} \mathrm{C}\right)$ e humidade $(40 \%-60 \%)$.

Os sujeitos realizaram o protocolo após um período de aclimatização de 1 minuto com os dois pés apoiados no chão (fase I), 1 minuto de marcha suave no mesmo local (1 passo por segundo) (fase II) e 1 minuto de recuperação, retomando a postura da fase inicial (fase III). A perfusão foi avaliada de forma não invasiva pelo sistema Tissue Viability (TiVi, Wheels Bridge, Suécia), um dispositivo de espectroscopia polarizada que consiste em uma câmara digital acoplada a filtros de polarização cruzada em frente a um conjunto de detetores, que polariza linearmente a luz visível da fonte de luz. Parte da luz incidente $(\sim 7 \%)$ é refletida com o estado de polarização original pela superfície da pele e bloqueada ou atenuada pelos filtros. A luz remanescente será difusamente retro difundida num estado despolarizado e que alcançam o detetor devido a eventos de dispersão e birrefringência nas camadas dérmicas superiores [9], onde os vasos microcirculatórios estão localizados. A foto é transmitida da câmara para o computador, onde a separação do plano de cores é realizada. A aplicação de um algoritmo baseado em dados dos planos de cor vermelha e verde, produz uma imagem pseudo-colorida, cujo valor de TiVi em cada pixel, é proporcional à concentração de hemácias em movimento dentro do volume real de dispersão no tecido. Este algoritmo baseia-se no conhecimento de que os comprimentos de onda verdes são absorvidos pela hemoglobina nos glóbulos vermelhos circulantes, enquanto, os comprimentos de onda vermelhos sofrem apenas uma pequena absorção [10]. O índice de TiVi expresso em unidades arbitrárias (AU) foi avaliado a uma taxa de amostragem de $6 \mathrm{~Hz}$ e a região de interesse (ROI) foi selecionada no dorso de ambos os pés, numa região anterior à articulação do tornozelo (Figura 1). A câmara foi posicionada a $100 \mathrm{~cm}$, o que permitiu manter o membro a uma distância maior que $60 \mathrm{~cm}$, eliminando a influência da temperatura e da intensidade luminosa da câmara [11].

Durante a fase de marcha (fase II), o índice TiVi foi avaliado em duas sub-fases - quando cada pé estava apoiado no chão, sustentando o peso corporal (fase de carga - C), e quando cada pé estava suspenso (fase de suspensão - SP). Para cada sub-fase, o índice TiVi foi calculado como o valor médio de todos os ciclos de marcha.

A Frequência de Pulso (FP) foi avaliada com um sensor de fotopletismografia (FPG) (sensor de volume sanguíneo de pulso, PLUX Biosignals, Portugal), colocado no segundo dedo da mão direita e ligado a uma placa 
test was used for foot comparisons within the same phase. A $p<0.05$ significance level was adopted. de microprocessador BITalino Plugged (PLUX Biosignals, Portugal ).

Os resultados foram expressos como os valores médios para cada pé. O teste dos postos sinalizados de Wilcoxon foi usado para comparações de fases em cada pé, e o teste de Mann-Whitney foi utilizado para comparações entre pés dentro da mesma fase. Foi adotado um nível de significância $\mathrm{p}<0,05$.

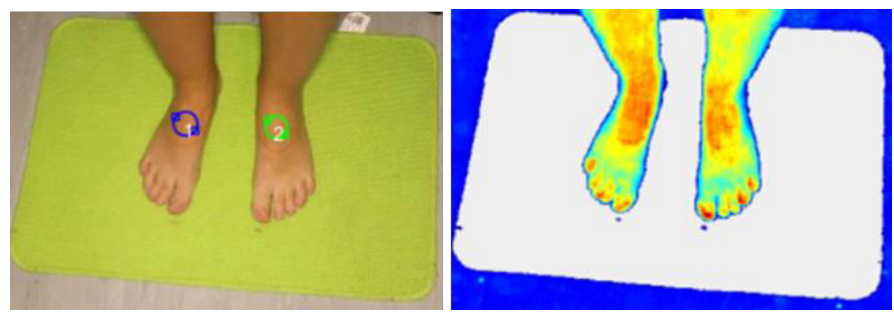

Figure 1/ Figura 1 - Region of the dorsum of both feet selected for the study/ Região dorsal do pé selecionada para o estudo

\section{Results and Discussion}

The PR was evaluated by the number of waves identified by the photoplethysmography for the three phases. As shown in Table 1, we have found no significant variations when comparing Phase I with Phase II ( $p=$ $0.892)$ and Phase I with Phase III $(p=0.752)$.

During Phase I, we could not find any perfusion differences between both feet ( $\mathrm{p}=0.485)$, meaning that in these conditions, involving normal healthy individuals, perfusion was equivalent in both limbs during rest. There are studies that refer to a tendency of different weight distribution between the two feet $[2,12]$, affecting microcirculation even at rest, but our results agree with previous studies carried out in the standing position using other measuring instruments, such as photoplethysmography and laser Doppler flowmetry $[5,7]$. The goal is to analyse in normal subjects variations of the microcirculation during gait, according to the periods when the feet were supported on the floor (loading) or during the step when each foot was suspended (suspension). Comparing values of the right foot of Phase I and the periods of support of the same foot during Phase II stepping, no significant differences were found $(p=0.116)$. The same was observed for the left foot in the same conditions $(p=0.173)$. Some authors report that pressure acts as an available functional stimuli from vascular morphology, allowing constant maintenance of blood flow according to the task [14-15].

The results were different when we compared each foot from Phase I with suspension in Phase II. Significant differences were found for both feet (right and left; $p$

\section{Resultados e Discussão}

A FP foi avaliada nas três fases pelo número de ondas identificadas na fotopletismografia. Como podemos verificar na Tabela 1 , não foram encontradas variações significativas quando comparadas a fase I com a fase II $(\mathrm{p}=0,892)$ e na comparação da fase I com a fase III ( $\mathrm{p}$ $=0,752$ ).

Durante a fase I, não verificámos diferenças de perfusão sanguínea entre os dois pés $(\mathrm{p}=0,485)$, significando que nestas condições, envolvendo indivíduos saudáveis normais, a perfusão é equivalente em ambos os membros durante o repouso. Há estudos que se referem a uma tendência de distribuição de peso diferente entre os dois pés $[2,12]$, afetando a microcirculação mesmo em repouso, mas os nossos resultados não o revelaram, concordando assim com estudos anteriormente realizados na posição de pé quando utilizados outros instrumentos de medição, como a fotopletismografia e a fluxometria por laser Doppler $[5,7]$.

O objetivo do trabalho foi analisar, em sujeitos normais, as variações da microcirculação durante a marcha, de acordo com os períodos em que os pés estavam apoiados no chão (carga) ou durante a etapa em que cada pé estava suspenso (suspensão). Comparando os valores do pé direito da fase I e os períodos de apoio do mesmo pé durante a fase II, não foram encontradas diferenças significativas $(\mathrm{p}=0,116)$. O mesmo foi observado para o pé esquerdo nas mesmas condições $(p=$ 0,173 ). Alguns autores relatam que a pressão atua como um estímulo funcional disponível a partir da morfologia vascular, permitindo a manutenção constante do 
$=0.046$ ), with mean values decreasing during Phase II suspension - for right foot $\mathrm{TiVi}$ values decreased from 223.8 in Phase I to 204.9 in Phase II, while on the left foot the descent was from 227.9 to 191.3 (Table 1). One of the biomechanical factors that may facilitate this local variation of the microcirculation is approached in a previous study that suggests that whenever a region of the body is subjected to a pressure as oposeed to a constant pressure, it causes a venous distension with subsequent reduction in locally blood flow [15-16]. In this way we considered that the pressure that the foot makes on the floor immediately before the suspension, together with the pressure exerted by the calf muscle pump during the withdrawal of the foot from the floor, increases the ascending progression of the blood flow. It is accepted that, in the standing position, calf muscle pumps are permanently activated, ensuring the upward direction of blood flow and that the plantar vascular pump activation that occurs immediately before, when the foot is still in support, is an important factor to the return circulation of lower limbs $[2,7,16]$. fluxo sanguíneo de acordo com a tarefa que está a ser realizada [14-15].

Em contraste, os resultados foram diferentes quando comparámos cada pé da fase I com a suspensão na fase II. Diferenças significativas foram encontradas para os dois pés (direito e esquerdo apresentaram valores de $p$ $=0,046)$, com os valores médios a diminuir durante a suspensão da fase II - os valores de TiVi do pé direito diminuíram de 223,8 na fase I para 204,9 na fase II, enquanto no pé esquerdo a descida foi de 227,9 para 191,3 (Tabela 1). Um dos fatores biomecânicos que podem facilitar essa variação local da microcirculação é abordado em estudos anteriores que sugerem que, sempre que uma região do corpo é submetida a uma pressão intermitente, ao contrário de uma pressão constante, provoca uma distensão venosa com consequente redução no fluxo sanguíneo local [15-16]. Desta forma, consideramos que a pressão que o pé faz no chão imediatamente antes da suspensão, juntamente com a pressão exercida pela bomba muscular da região posterior da perna durante a retirada do pé do chão, aumenta a progressão ascendente do fluxo sanguíneo.

Table 1/ Tabela 1 - Mean and standard deviation of the parameters calculated for the three phases of the protocol. LP - Loading sub-phase : SP - Suspension sub-phase $(*-p<0.05$; AU arbitrary units)/Média e desvio-padrão dos parâmetros calculados para as três fases do protocolo. $\mathrm{C}$ - subfase de Carga; subfase suspensão(* $-\mathrm{p}<0.05$; UA unidades arbitrarias).

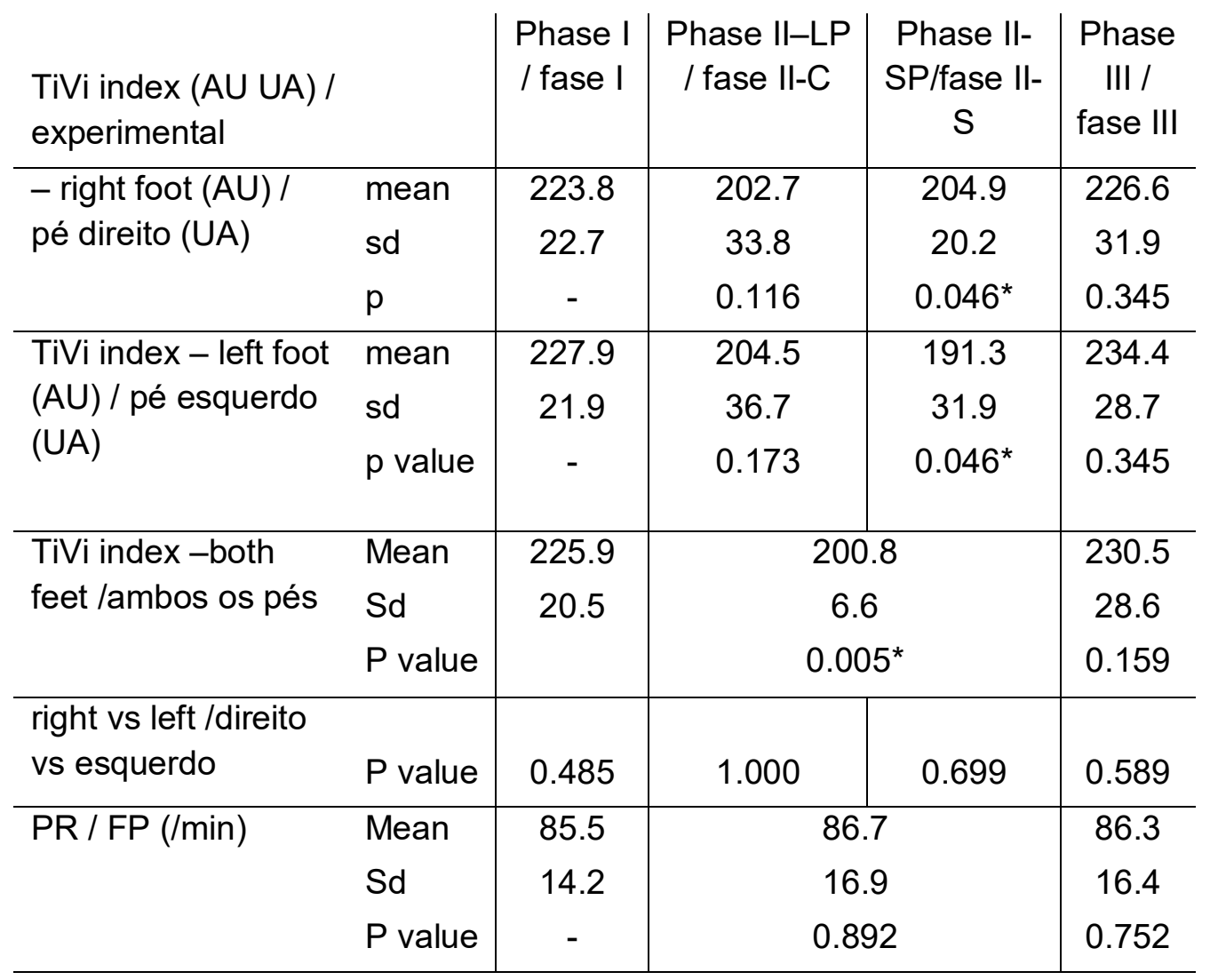


In the comparison of each foot between Phase I and the recovery phase (Phase III), no changes were recorded (similar statistical values with $\mathrm{p}=0.345$ for both feet), which indicates that in normal individuals with this type of gait, the values rested immediately after the activity is completed (Table 1). Recovery time is one of the indicators of hemodynamic regulation capacity [17].

We also identified whether the movements of the foot during the step (Phase II in general) showed variations of the microcirculation relative to Phase I and found significant differences between the two phases, with $p$ $=0.005$. It should be noted that subjects performed one step per second, making 60 steps that they themselves controlled with a stopwatch during the minute of the Phase II $[15,17]$.

This gait was performed with smooth effortless strokes, causing a minimum of rapid pressure stimuli, so we believe that the oscillations observed with the measuring system occur constantly and are more pronounced with intermittent physical mechanisms. These preliminary results are indicative of the importance of future studies to know how diverse mechanisms induce physiological variations in microcirculation and how they can be used to minimize peripheral vascular diseases. The study of the microcirculation in the lower limbs may be relevant to the pathophysiology of vascular diseases associated with changes in gait parameters such as cadence and alternate weight transfer in the feet.

\section{Conclusion}

Our preliminary data suggest a variation in values of concentration of moving red blood cells in the skin microcirculation of the lower limb, according to the movements associated with the gait as the foot is loading or in the suspension on the ground. These physiological variations may be related to oscillatory biomechanical factors present during this activity. Further studies are needed to confirm the microvascular behaviour on the lower limb during the gait cycle.
É aceite que, na posição ortostática, as bombas musculares da perna são permanentemente ativadas, garantindo a direção ascendente do fluxo sanguíneo e que a ativação da bomba vascular plantar que ocorre imediatamente antes, quando o pé ainda está em apoio, é um fator importante para o retorno da circulação dos membros inferiores $[2,7,16]$.

Na comparação de cada pé entre a fase I e a fase de recuperação (Fase III), não foram registradas alterações (valores estatísticos semelhantes com $\mathrm{p}=0,345$ para ambos os pés), o que indica que em indivíduos normais com esse tipo de marcha, os valores recuperam imediatamente após a conclusão da atividade (Tabela 1). O tempo de recuperação é um dos indicadores da capacidade de regulação hemodinâmica [17].

Identificámos também se os movimentos do pé durante a passada (fase II em geral) mostraram variações da microcirculação em relação à fase I e encontrámos diferenças significativas entre as duas fases, com $p=0,005$. Deve-se notar que os sujeitos realizaram um passo por segundo, realizando 60 degraus que eles mesmos controlaram com um cronômetro durante a hora da fase II $[15,17]$.

Esta marcha foi realizada com movimentos suaves e sem esforço, causando um mínimo de estímulos de pressão rápida, por isso acreditamos que as oscilações observadas com o sistema de medição ocorrem constantemente e são mais pronunciadas pelos mecanismos físicos intermitentes. Estes resultados preliminares são indicativos da importância de estudos futuros para saber como os vários mecanismos induzem variações fisiológicas na microcirculação e como podem ser usados para minimizar as doenças vasculares periféricas. $\mathrm{O}$ estudo da microcirculação nos membros inferiores pode ser relevante para a fisiopatologia das doenças vasculares, associada a alterações nos parâmetros da marcha, como a cadência e a transferência de peso alternada nos pés.

\section{Conclusão}

Os nossos dados preliminares sugerem uma variação nos valores de concentração do movimento das hemácias na microcirculação da pele do membro inferior, de acordo com os movimentos associados à marcha à medida que o pé está em apoiio ou em suspensão no solo. Essas variações fisiológicas podem estar relacionadas com fatores biomecânicos oscilatórios presentes durante esta atividade. Mais estudos são necessários para confirmar o comportamento microvascular no membro inferior durante o ciclo da marcha. 


\section{Acknowledgements}

The authors would like to express their thanks to all the volunteers for their participation in this study. This work was supported by national funds from FCT, within the project UID/DTP/04567/2016

\section{Conflict of Interest}

The authors declare that there is no financial or personal relationship that can be understood as representing any potential conflict of interest.

\section{Agradecimentos}

Os autores agradecem a todos os voluntários pela participação neste estudo. Este trabalho foi financiado por fundos nacionais da FCT, dentro do projeto UID / DTP / 04567/2016

\section{Conflito de interesses}

Os autores declaram que não existe uma relação financeira ou pessoal que possa ser entendida como representando um potencial conflito de interesses.

\section{References/ Referências}

1 - Caldwell J, Wardlow G, Branch P, Ramos M, Black C, Ade C. Effect of exercise-induced muscle damage on vascular function and skeletal muscle microvascular deoxygenation. Physiol Reports, 2016,4 (22), e13032.

2. McGowan CP, Neptune RR, Clark DJ, Kautz SA. Modular control of human walking: Adaptations to altered mechanical demands. Journal of biomechanics.2010 Feb 10;43(3):412-9

3. Takeda R, Lisco G, Fujisawa T, Gastaldi L, Tohyama H, Tadano S. Drift Removal for Improving the Accuracy of Gait Parameters Using Wearable Sensor Systems. Sensors 2014, 14, 23230-2324 7; DOI:10.3390/s141223230

4. Neptune RR, Clark DJ, Kautz SA. Modular control of human walking: a simulation study. Journal of biomechanics. 2009 Jun 19; 42(9):1282-7

5. Florindo M, Silva H, Monteiro Rodrigues. Impact of the isometric contraction of the calf on the local microcirculation Biomedical Sciences/Ciências Biomédicas Biomed Biopharm Res. 2017; (14) 2: 179-186. DOI: 10.19277/bbr.14.2.160

6. Silva H, Ferreira H, Bujan J, Monteiro Rodrigues L. Exploring the oxygen challenge test as a microcirculation evaluation model. Biomed Biopharm Res. 2013; (10) 2: 209-215.

7. Carter SJ; Hodges GJ. Sensory and sympathetic nerve contributions to the cutaneous vasodilator response from a noxious heat stimulus. 2011. Exp Physiol 96.11 pp 1208-1217. DOI: 10.1113/expphysiol.2011.059907

8. World Medical Association Declaration of Helsinki Ethical Principles for Medical Research Involving Human Subjects. JAMA. 2013; 310(20):2191-2194

9. O’Doherty J, Henricson J, Anderson C, Leahy MJ, Nilsson G,4 Sjo"berg F. Sub-epidermal imaging using polarized light spectroscopy for assessment of skin microcirculation. Skin Research and Technology 2007; 13: 472-484 \& 2007. DOI: 10.1111/j.1600-0846.2007.00253.x

10. Costello JT, McNamara PM, O'Connell ML, Algar LA, Leahy MJ, Donnelly AE. Tissue viability imaging of skin microcirculation following exposure to whole body cryotherapy $\left(-110^{\circ} \mathrm{C}\right)$ and cold water immersion $\left(8^{\circ} \mathrm{C}\right) .2014$. Arch Exerc Health Dis 4 (1): 243-250. DOI: 10.5628/aehd.v4i1.152

11. Nilsson G, Zhai H, Chan H, Farahmand S, Maibach HI. Cutaneous bioengineering instrumentation standardization: the Tissue Viability Imager. Skin Research and Technology 2009; 15: 6-13. DOI: 10.1111/j.1600-0846.2008.00330.x

12. Marencakova J, Maly T, Sugimoto D, Gryc T, Zahalka F (2018) Foot typology, body weight distribution, and postural stability of adolescent elite soccer players: A 3-year longitudinal study. PLoS ONE 13(9): e0204578. DOI:org/10.1371/journal.pone.0204578

13. Pries A, Secomb T. Modeling structural adaptation of microcirculation. Microcirculation. 2008 November; 15(8): 753-764. DOI: $10.1080 / 10739680802229076$

14. Kubasch ML, Kubasch AS, Torres Pacheco J, Buchmann SJ, Illigens BM, Barlinn K and Siepmann T. Laser Doppler Assessment of Vasomotor Axon Reflex Responsiveness to Evaluate Neurovascular Function. 2017. Front. Neurol. 8:370. DOI: 10.3389/fneur.2017.00370

15. Meissner MH, Moneta G, Burnand K, Gloviczki P, Lohr JM, Lurie F, et al. The hemodynamics and diagnosis of venous disease. Journal of vascular surgery. 2007 Dec;46 Suppl S:4S-24S.

16. Sundby ØH, Høiseth LØ, Mathiesen I, Weedon-Fekjñr H, Sundhagen JO, Hisdal J (2017) The acute effects of lower limb intermittent negative pressure on foot macro - and microcirculation in patients with peripheral arterial disease. PLoS ONE 12(6): e0179001. https://DOI. org/10.1371/journal. pone. 0179001

17. Wang H, Zhang Y-feng, Xu L-liang, et al. Step rate-determined walking intensity and walking recommendation in Chinese young adults: a crosssectional study. BMJ Open 2013;3:e 001801. DOI:10.1136/ bmjopen-2012-001801

18. Fronek A, Vanderweijer I. Noninvasive determination of venomuscular efficiency. Journal of Vascular Surgery. 2003. Volume 37, Number 4

19. Tanno J, Gatate Y, Kasai T, Nakano S, Senbonmatsu T, Sato O, et al. A Novel Index Using Ankle Hemodynamic Parameters to Assess the Severity of Peripheral Arterial Disease: A Pilot Study. PLoS ONE, 2016. 11(10): e0164756. doi:10.1371/journal.pone.0164756

20. Stoller M, Stoller D, Seiler C. Physical exercise and quantitative lower limb collateral function. Open heart. 2016. $3(1): \mathrm{e} 000355$.

21. Raju S, Sanford P, Herman S, Olivier J. Postural and Ambulatory Changes in Regional Flow and Skin Perfusion. European Journal of Vascular and Endovascular Surgery 43 (2012) 567e572. DOI:10.1016/j.ejvs.2012.01.019 